\title{
A commercially available energy drink does not improve peak power production on multiple 20-second Wingate tests
}

\author{
Bill I Campbell ${ }^{1 *}$, Marcus Kilpatrick', Colin Wilborn², Paul La Bounty ${ }^{3}$, Brittany Parker ${ }^{1}$, Brittany Gomez ${ }^{1}$, Ava Elkins ${ }^{1}$, \\ Sean Williams ${ }^{1}$, Maria Gisele dos Santos ${ }^{4}$
}

From International Society of Sports Nutrition; 7th Annual ISSN Conference and Expo

Clearwater Beach, FL, USA. 24-26 June 2010

\section{Background}

Energy drinks are often marketed to the consumer as a performance enhancing beverage. When performance benefits are realized, it is likely due to the caffeine content present in typical energy drinks. There have been few scientific studies investigating the effects of energy drink ingestion on anaerobic performance assessed by repeated 20-second Wingate tests. PURPOSE: To determine the effects of a caffeine-containing, commercially available energy drink on peak power produced during two, 20-second Wingate tests separated by 150 seconds.

\section{Methods}

In a randomized (order of beverage), double blind, placebo controlled cross-over design, 15 recreationally active subjects $(9$ males and 6 females; $21.7 \pm 1.6$ yrs; $172.7 \pm 10.3 \mathrm{~cm} ; 75.1 \pm 20.2 \mathrm{~kg})$ ingested a commercially available energy drink (containing $160 \mathrm{mg}$ of caffeine) or a placebo beverage that was matched for carbohydrate content and was similar in volume and texture. The average relative caffeine dosage for each participant was $2.1 \mathrm{mg} / \mathrm{kg}$. Approximately 60 minutes following ingestion of the energy drink or carbohydrate placebo, each participant engaged in two 20-second Wingate tests (Monark 894 E Peak Bike ${ }^{\odot}$ ). Approximately one week later, each participant engaged in the same protocol but ingested the other beverage. To serve as a warm-up prior to the first Wingate test at each trial, each participant was instructed to lightly jog for approximately 90 seconds, perform multiple vertical jumps, and then cycle at a self-selected pace for

${ }^{1}$ University of South Florida, Exercise and Performance Nutrition Laboratory, Tampa, FL , USA

Full list of author information is available at the end of the article approximately 5 minutes. Following the warm-up, each participant performed two 20-second Wingate tests with each test separated by approximately 150 seconds. Peak power (measured in watts) for each of the two trials was recorded for statistical analysis. Peak power performance was analyzed via within-subjects repeated measures ANOVA using SPSS for Windows 15.0.

\section{Results}

The peak power achieved after ingesting the energy drink for the two Wingate tests (separated by $150 \mathrm{sec}-$ onds) was $786.4 \pm 245.9$ and $722 \pm 242$ watts for the first and second tests, respectively. The peak power achieved after ingesting the carbohydrate placebo beverage for the two Wingate tests (separated by $150 \mathrm{sec}-$ onds) was $777.1 \pm 276$ and $716.7 \pm 247.6$ watts for the first and second tests, respectively.. The repeated measures ANOVA revealed that there was not a significant main effect for supplement ( $\mathrm{p}=0.495)$; but there was a significant main effect for time (the peak power was significantly higher for the first Wingate test as compared to the second Wingate test, irrespective of supplement; $p=0.001$ ). Finally, there was no significant interaction between the energy drink and placebo beverage in relation to peak power production $(\mathrm{p}=0.877)$.

\section{Conclusion}

Ingesting a caffeine-containing energy drink (160 mg of caffeine) 60 minutes prior to performing two 20 -second Wingate tests will not improve peak power production.

\section{Acknowledgment}

This investigation was supported by a University of South Florida College of Education Mini-Grant. 


\section{Author details}

${ }^{1}$ University of South Florida, Exercise and Performance Nutrition Laboratory, Tampa, FL , USA . ' University of Mary-Hardin Baylor, Human Performance Laboratory, Belton, TX, USA . ${ }^{3}$ Baylor University, Exercise and Sport Nutrition Laboratory Waco, TX, USA . ${ }^{4}$ Federal University of Paraná, Curitiba, Paraná, Brazil.

Published: 15 September 2010

doi:10.1186/1550-2783-7-S1-P10

Cite this article as: Campbell et al: A commercially available energy

drink does not improve peak power production on multiple 20-second Wingate tests. Journal of the International Society of Sports Nutrition 2010 7(Suppl 1):P10.

Submit your next manuscript to BioMed Central and take full advantage of:

- Convenient online submission

- Thorough peer review

- No space constraints or color figure charges

- Immediate publication on acceptance

- Inclusion in PubMed, CAS, Scopus and Google Scholar

- Research which is freely available for redistribution

Submit your manuscript at www.biomedcentral.com/submit
C Biomed Central 